\title{
Research Paper on Green Marketing
}

\author{
Ameet Sao, \\ M.B.A.(Assistant Professor) Shaheed Sukhdev College Of Business Studies (University Of Delhi)
}

\begin{abstract}
Green marketing is a phenomenon which has developed particular important in the modern market. This concept hasenabled for the re-marketing and packaging of existingproducts which already adhere to such guidelines.Additionally, the development of green marketing has openedthe door of opportunity for companies to co-brand theirproducts into separate line, lauding the green-friendliness ofsome while ignoring that of others. Such marketingtechniques will be explained as a direct result of movement inthe minds of the consumer market. As a result of thisbusinesses have increased their rate of targeting consumerswho are concerned about the environment. These sameconsumers through their concern are interested in integratingenvironmental issues into their purchasing decisions throughtheir incorporation into the process and content of themarketing strategy for whatever product may be required.This paper discusses how businesses have increased theirrate of targeting green consumers, those who are concernedabout the environment and allow it to affect their purchasingdecisions. The paper identifies the three particular segmentsof green consumers and explores the challenges andopportunities businesses have with green marketing. Thepaper also examines the present trends of green marketing inIndia and describes the reason why companies are adopting itand future of green marketing and concludes that greenmarketing is somethingthat will continuously grow in bothpractice and demand.
\end{abstract}

\section{Introduction}

According to the American Marketing Association, greenmarketing is the marketing of products that are presumed tobe environmentally safe. Thus green marketing incorporates abroad range of activities, including product modification,changes to the production process, packaging changes, aswell as modifying advertising. Yet defining green marketingis not a simple task where several meanings intersect andcontradict each other; an example of this will be the existenceof varying social, environmental and retail definitionsattached to this term. Other similar terms used areEnvironmental Marketing and Ecological Marketing. Thus"Green Marketing" refers to holistic marketing conceptwherein the production, marketing consumption an disposalof products and services happen in a manner that is lessdetrimental to the environment with growing awarenessabout the implications of global warming, non-biodegradablesolid waste, harmful impact of pollutants etc., both marketersand consumers are becoming increasingly sensitive to theneed for switch in to green products and services. While theshift to "green" may appear to be expensive in the short term, it will definitely prove to be indispensable and advantageous,cost-wise too, in the long run.

Green marketing, also alternativelyknown as environmental marketing and sustainablemarketing, refers to an organization's efforts at designing,promoting, pricing and distributing products that will notharm the environment

\section{Why Green Marketing}

It is really scary to read these pieces of information as reported in the Times recently: "Air pollution damage to people, crops and wildlife in US. Total tens of billions of dollars each year". "More than 12 other studies in the US, Brazil Europe, Mexico, South Korea and Taiwan have established links between air pollutants and low birth weight premature birth still birth and infant death". As resources are limited and human wants are unlimited, it is important for the marketers to utilize the resources efficiently without waste as well as to achieve the organization's objective. So green marketing is inevitable. There is growing interest among the consumers all over the world regarding protection of environment. Worldwide evidence indicates people are concerned about the environment and are changing their behavior. As a result of this, green marketing has emerged which speaks for growing market for sustainable and socially responsible products and services. Thus the growing awareness among the consumers all over the world regarding protection of the environment in which they live, People do want to bequeath a clean earth to their offspring. Various studies by environmentalists indicate thatpeople are concerned about the environment and are changingtheir behavior pattern so as to be less hostile towards it. Nowwe see that most of the consumers, both individual andindustrial, are becoming more concerned about environmentfriendlyproducts.

According to Peattie (2001), the evolution of green marketinghas three phases. First phase was termed as "Ecological"green marketing, and during this period all marketingactivities were concerned to help environment 
problems andprovide remedies for environmental problems. Second phasewas "Environmental" green marketing and the focus shiftedon clean technology that involved designing of innovativenew products, which take care of pollution and waste issues. Third phase was "Sustainable" green marketing. It came intoprominence in the late 1990s and early 2000.

\section{Green Products And Its Characteristics}

The products those are manufactured through greentechnology and that caused no environmental hazards arecalled green products. Promotion of green technology andgreen products is necessary for conservation of naturalresources and sustainable development. We can define greenproducts by following measures:

- Products those are originally grown,

- Products those are recyclable, reusable and biodegradable,

- Products with natural ingredients,

- Products containing recycled contents, non-toxicchemical,

- Products contents under approved chemical,

- Products that do not harm or pollute the environment,

- Products that will not be tested on animals,

- Products that have eco-friendly packaging i.e. reusable,refillable containers etc.

\section{Need Of Green Marketing: An Anthropological View}

Issues like Global warming and depletion of ozone umbrellaare the main for the healthy survival. Every person rich orpoor would be interested in quality life with full of health andvigor and so would the corporate class. Financial gain andeconomic profit is the main aim of any corporate business.But harm to environment cost by sustain business across theglobe is realized now though off late. This sense is buildingcorporate citizenship in the business class. So greenmarketing by the business class is still in the selfishanthological perspective of long term sustainable businessand to please the consumer and obtain the license by the governing body. Industries in Asian countries are catching theneed of green marketing from the developed countries but stillthere is a wide gap between their understanding andimplementation.

\section{- $\quad$ Need for Standardization}

\section{Challenges In Green Marketing}

It is found that only $5 \%$ of the marketing messages from "Green" campaigns are entirely true and there is a lack ofstandardization to authenticate these claims. There is nostandardization to authenticate these claims. There is nostandardization currently in place to certify a product asorganic. Unless some regulatory bodies are involved inproviding the certifications there will not be any verifiablemeans. A standard quality control board needs to be in placefor such labeling and licensing.

\section{- New Concept}

Indian literate and urban consumer is getting more awareabout the merits of Green products. But it is still a newconcept for the masses. The consumer needs to be educatedand made aware of the environmental threats. The new greenmovements need to reach the masses and that will take a lot oftime and effort. By India's ayurvedic heritage, Indianconsumers do appreciate the importance of using natural andherbal beauty products. Indian consumer is exposed tohealthy living lifestyles such as yoga and natural foodconsumption. In those aspects the consumer is already awareand will be inclined to accept the green products.

\section{- Patience and Perseverance}

The investors and corporate need to view the environment as amajor long-term investment opportunity, the marketers needto look at the long-term benefits from this new greenmovement. It will require a lot of patience and no immediateresults. Since it is a new concept and idea, it will have its ownacceptance period.

\section{- $\quad$ Avoiding Green Myopia}

The first rule of green marketing is focusing on customerbenefits i.e. the primary reason why consumers buy certainproducts in the first place. Do this right, and motivateconsumers to switch brands or even pay a premium for thegreener alternative. It is not going to help if a product isdeveloped which is absolutely green in various aspects butdoes not pass the customer satisfaction criteria. This will leadto green myopia. Also if the green products are priced veryhigh then again it will lose its market acceptability. 


\section{Golden Rules Of Green Marketing}

1. Know you're Customer: Make sure that the consumer isaware of and concerned about the issues that your productattempts to address, (Whirlpool learned the hard way thatconsumers wouldn't pay a premium for a CFC-free refrigerator because consumers dint know what CFCs were.).

2. Educating your customers: isn't just a matter of letting people know you're doing whatever you're doing to protect the environment, but also a matter of letting them know why it matters. Otherwise, for a significant portion of your target market, it's a case of "So what?" and your green marketing campaign goes nowhere.

3. Being Genuine \& Transparent: means that a) you are actually doing what you claim to be doing in your green marketing campaign and $\mathbf{b}$ ) the rest of your business policies are consistent with whatever you are doing that's environmentally friendly. Both these conditions have to be met for your business to establish the kind of environmental credentials that will allow a green marketing campaign to succeed.

4. Reassure the Buyer: Consumers must be made to believe that the product performs the job it's supposed to do-they won't forego product quality in the name of the environment.

5. Consider Your Pricing: If you're charging a premium for your product-and many environmentally preferable products cost more due to economies of scale and use of higher-quality ingredients-make sure those consumerscan afford the premium and feel it's worth it.

6. Giving your customers an opportunity to participate: means personalizing the benefits of your environmentally friendly actions, normally through letting the customer take part in positive environmental action.

7. Thus leading brands should recognize that consumer expectations have changed: It is not enough for a company to green its products; consumers expect the products that they purchase pocket friendly and also to help reduce the environmental impact in their own livestoo.

\section{Green Marketing - Adopts By The Farms}

Green marketing has been widely adopted by the firmsworldwide and the following are the possible reasons cited forthis wide adoption:

1. Opportunities - As demand changes, many firms see these changes as an opportunity to exploit and have a competitive advantage over firms marketing non-environmentally responsible alternatives. Some examples of firms who have strived to become more environmentally responsible, in an attempt to better satisfy their consumer needs are:

- McDonald's replaced its clam shell packaging withwaxed paper because of increased consumer concernrelating to polystyrene production and Ozonedepletion.

- Tuna manufacturers modified their fishingtechniques because of the increased concern overdriftnet fishing, and the resulting death of dolphins.

- Xerox introduced a "high quality" recycledphotocopier paper in an attempt to satisfy thedemands of firms for less environmentally harmfulproducts.

2. Government Pressure - As with all marketing related activities, governments want to "protect" consumer and society; this protection has significant green marketing implications. Government regulations relating to environmental marketing are designed to protect consumers in several ways,

- Reduce production of harmful goods or by-products Modify consumer and industry's use and/or consumption of harmful goods

- Ensure that all types of consumers have the ability to evaluate the environmental composition of goods. Government establishes regulations designed to control the amount of hazardous wastes produced by firms.

3. Competitive Pressure - Another major force in the environmental marketing area has been firms' desire to maintain their competitive position. In many cases firms observe competitors promoting their environmental behaviors and attempt to emulate this behavior. In some instances this competitive pressure has caused an entire industry to modify and thus reduce its detrimental environmental behavior. For example when one tuna manufacture stopped using driftnets the others followed suit.

4. Social Responsibility - Many firms are beginning to realize that they are members of the wider community and therefore must behave in an environmentally responsible fashion. This translates into firms that believe they must achieve environmental objectives as well as profit related objectives. This result in environmental issues being integrated into the firm's corporate culture. There are examples of firms adopting both strategies.

5. Cost of Profit Issues - Firms may also use green marketing in an attempt to address cost or profit related issues. Disposing of environmentally harmful byproducts, such as polychlorinated biphenyl (PCB) contaminated oil are becoming increasingly costly and in some cases difficult. Therefore firms that can reduce harmful wastes may incur substantial cost savings. When attempting to minimize waste, 
firms are often forced to re-examine their production processes. In these cases they often develop more effective production processes that not only reduce waste, but reduce the need for some raw materials.

\section{Some Cases}

Interestingly, green marketing continues to be an issue of $\mathbf{5}$ global interests. In fact, Google Trends reports that, on arelative basis, more searches for "green marketing"originated from India than from any other country.

\begin{tabular}{|l|l|l|l|l|l|l|l|}
\hline Rank & 1 & 2 & 3 & 4 & 5 & 6 & 6 \\
\hline Country & India & UK & US & Thailand & Australia & Canada & China \\
\hline
\end{tabular}

Many companies are adopting green for capturing marketopportunity of green marketing some cases

\section{EXAMPLE 1: Best Green IT Project: State Bank ofIndia: Green IT@ SBI}

By using eco and power friendly equipment in its 10,000 newATMs, the banking giant has not only saved power costs andearned carbon credits, but also set the right example forothers to follow.

SBI is also entered into green service known as "GreenChannel Counter". SBI is providing many services like; paperless banking, no deposit slip, no withdrawal form, no checks, no money transactions form all these transaction are donethrough SBI shopping \& ATM cards. State Bank of India turnsto wind energy to reduce emissions: The State Bank of Indiabecame the first Indian bank to harness wind energy through a15megawatt wind farm developed by Suzlon Energy. Thewind farm located in Coimbatore uses 10 Suzlon windturbines, each with a capacity of $1.5 \mathrm{MW}$. The wind farm isspread across three states - Tamil Nadu, with 4.5 MW of windcapacity; Maharashtra, with $9 \mathrm{MW}$; and Gujarat, with 1.5MW. The wind project is the first step in the State Bank ofIndia's green banking program dedicated to the reduction ofits carbon footprint and promotion of energy efficientprocesses, especially among the bank's clients.

\section{EXAMPLE 2: Lead Free Paints from Kansai Nerolac}

Kansai Nerolac Paints Ltd. has always been committed to thewelfare of society and environment and as a responsiblecorporate has always taken initiatives in the areas of health,education, community development and environmentpreservation.

Kansai Nerolac has worked on removing hazardous heavymetals from their paints. The hazardous heavy metals likelead, mercury, chromium, arsenic and antimony can haveadverse effects on humans. Lead in paints especially posesdanger to human health where it can cause damage to CentralNervous System, kidney and reproductive system. Childrenare more prone to lead poisoning leading to lower intelligencelevels and memory loss.

\section{EXAMPLE 3: Indian Oil's Green Agenda \\ Green Initiatives}

- Indian Oil is fully geared to meet the target of reachingEURO-III compliant fuels to all parts of the country bythe year 2010; major cities will upgrade to Euro-IVcompliant fuels by that time.

- Indian Oil has invested about Rs. 7,000 crore so far ingreen fuel projects at its refineries; ongoing projectsaccount for a further Rs. 5,000 crore.

- Motor Spirit Quality Improvement Unit commissioned atMathura Refinery; similar units are coming up at threemore refineries.

- Diesel quality improvement facilities in place at all sevenIndian Oil refineries, several more green fuel projects areunder implementation or on the anvil.

- The R\&D Centre of Indian Oil is engaged in theformulations of eco-friendly biodegradable lubeformulations.

- The Centre has been certified under ISO-14000:1996 forenvironment management systems.

\section{EXAMPLE 4: India's 1st Green Stadium}

The Thyagaraja Stadium stands tall in the quiet residentialcolony behind the Capital's famous INA Market. It was jointlydedicated by Union Sports Minister MS Gill and ChiefMinister Sheila Dikshit on Friday.Dikshit said that the stadium is going to be the first greenstadium in India, which has taken a series of steps to ensureenergy conservation and this stadium has been constructed asper the green building concept with eco-friendly materials. 


\section{EXAMPLE 5: Eco-friendly Rickshaws before CWG}

Chief minister ShielaDikshit launched on (year not mentioned) Tuesday a batteryoperatedrickshaw, "E-rick", sponsored by a cellular servicesprovider, to promote eco-friendly transportation in the cityahead of the Commonwealth Games.

\section{Present Trends In Green: Marketing In India}

Organizations are Perceive Environmental marketing asan Opportunity to achieve its objectives. Firms haverealized that consumers prefer products that do not harmthe natural environment as also the human health. Firmsmarketing such green products are preferred over theothers not doing so and thus develop a competitiveadvantage, simultaneously meeting their businessobjectives. Organizations believe they have a moral obligation to bemore socially responsible. This is in keeping with thephilosophy of CSR which has been successfully adoptedby many business houses to improve their corporateimage. Firms in this situation can take two approaches:

- Use the fact that they are environmentallyresponsible as a marketing tool.

- Become responsible without prompting this fact.

Governmental Bodies are forcing Firms to BecomeMore Responsible. In most cases the government forcesthe firm to adopt policy which protects the interests ofthe consumers. It does so in following ways:

- Reduce production of harmful goods or byproducts

- Modify consumer and industry's use and /orconsumption of harmful goods; or

- Ensure that all types of consumers have the abilityto evaluate the environmental composition ofgoods.

Competitors' Environmental Activities Pressure Firmsto change their Environmental Marketing Activities. Inorder to get even with competitors claim to beingenvironmentally friendly, firms change over to greenmarketing. Result is green marketing percolates entireindustry.

Cost Factors Associated With Waste Disposal orReductions in Material Usage Forces Firms to Modifytheir Behavior. With cost cutting becoming part of thestrategy of the firms it adopts green marketing in relationto these activities. It may pursue these as follows:

- A Firm develops a technology for reducing wasteand sells it to other firms.

- A waste recycling or removal industry develops.

\section{The Future Of Green Marketing}

There are many lessons to be learned to be learned to avoidgreen marketing myopia, the short version of all this is thateffective green marketing requires applying good marketingprinciples to make green products desirable for consumers.The question that remains, however, is, what is greenmarketing's future? Business scholars have viewed it as a"fringe" topic, given that environmentalism's acceptance oflimits and conservation does not mesh well with marketing'straditional axioms of "give customer what they want" and"sell as much as you can".Evidence indicates that successfulgreen products have avoided green marketing myopia byFollowing three important principles:

\section{Consumer Value Positioning}

- Design environmental products to perform as well as (orbetter than) alternatives.

- Promote and deliver the consumer desired value ofenvironmental products and target relevant consumermarket segments.

- Broaden mainstream appeal by bundling consumerdesired value into environmental products.

\section{Calibration Of Consumer Knowledge}

- Educate consumers with marketing messages thatconnect environmental attributes with desired consumervalue.

- Frame environmental product attributes as "solutions"for consumer needs.

- Create engaging and educational internet sites aboutenvironmental products desired consumer value.

\section{Credibility Of Product Claim}

- Employ environmental product and consumer benefitclaims that are specific and meaningful.

- Procure product endorsements or eco-certifications fromtrustworthy third parties and educate consumers aboutthe meaning behind those endorsements and eco-certifications.

- Encourage consumer evangelism via consumers socialand internet communication network with compelling,interesting and entertaining information aboutenvironmental products. 


\section{Conclusion}

Now this is the right time to select "Green Marketing"globally. It will come with drastic change in the world ofbusiness if all nations will make strict roles because greenmarketing is essential to save world from pollution. From thebusiness point of view because a clever marketer is one whonot only convinces the consumer, but also involves theconsumer in marketing his product. Green marketing shouldnot be considered as just one more approach to marketing, buthas to be pursued with much greater vigor, as it has anenvironmental and social dimension to it. With the threat ofglobal warming looming large, it is extremely important thatgreen marketing becomes the norm rather than an exceptionor just a fad. Recycling of paper, metals, plastics, etc., in a safeand environmentally harmless manner should become muchmore systematized and universal. It has to become the generalnorm to use energy-efficient lamps and other electrical goods.Marketers also have the responsibility to make the consumersunderstand the need for and benefits of green products ascompared to nongreen ones. In green marketing, consumersare willing to pay more to maintain a cleaner and greenerenvironment. Finally, consumers, industrial buyers andsuppliers need to pressurize effects on minimize the negativeeffects on the environment-friendly. Green marketingassumes even more importance and relevance in developingcountries like India.

\section{References}

[1]. J.A Ottman, et al, "Avoiding Green Marketing Myopia",Environment, Vol-48, June-2006

[2]. www.greenmarketing.net/stratergic.html

[3]. www.epa.qld.gov.au/sustainable_industries

[4]. www.greenpeace.org/international

[5]. www.google.com

[6]. http://www.iocl.com/AboutUs/environment\%28GFA\%29.aspx 